\section{DIGITAL COMMONS \\ @ UNIVERSITY OF SOUTH FLORIDA}

\section{ABO: Interactive Journal for Women in the Arts, 1640-1830}

Volume 3

Issue 2 Volume 3.2 (Fall 2013)

Article 6

2013

\title{
Poetry Archives on the Web: Thomas Gray Archive, The Poetry of the Gentleman's Magazine, 1731-1800: An Electronic Database of Titles, Authors, and First Lines, and The Poetess Archive
}

Kate Parker

University of Wisconsin - La Crosse, kparker@uwlax.edu

Follow this and additional works at: https://digitalcommons.usf.edu/abo

Part of the Dramatic Literature, Criticism and Theory Commons, Educational Methods Commons, Feminist, Gender, and Sexuality Studies Commons, and the Literature in English, British Isles Commons

\section{Recommended Citation}

Parker, Kate (2013) "Poetry Archives on the Web: Thomas Gray Archive, The Poetry of the Gentleman's Magazine, 1731-1800: An Electronic Database of Titles, Authors, and First Lines, and The Poetess Archive," ABO: Interactive Journal for Women in the Arts, 1640-1830: Vol.3: Iss.2, Article 6. http://dx.doi.org/10.5038/2157-7129.3.2.6

Available at: https://digitalcommons.usf.edu/abo/vol3/iss2/6

This Reviews is brought to you for free and open access by Digital Commons @ University of South Florida. It has been accepted for inclusion in ABO: Interactive Journal for Women in the Arts, 1640-1830 by an authorized administrator of Digital Commons @ University of South Florida. For more information, please contact digitalcommons@usf.edu. 
Poetry Archives on the Web: Thomas Gray Archive, The Poetry of the Gentleman's Magazine, 1731-1800: An Electronic Database of Titles, Authors, and First Lines, and The Poetess Archive

\author{
Abstract \\ Recent innovations in digital scholarship have enabled new online archives, editions and bibliographies to \\ flourish. Three such online resources--the Thomas Gray Archive, the Poetess Archive, and The Poetry of \\ the Gentleman's Magazine, 1731-1800: An Electronic Database of Titles, Authors, and First Lines--are \\ explored in depth in this review, with an eye to how each archive specifically encourages scholarly \\ collaboration and makes use of crowd-sourcing technologies.

\section{Keywords} \\ digital archive, digital scholarship, Thomas Gray, Poetess, Gentleman's Magazine, crowd-sourcing, poetry \\ Creative Commons License \\ (c) (i) $\ominus$
}

This work is licensed under a Creative Commons Attribution-No Derivative Works 3.0 License. 
Poetry Archives on the Web: Thomas Gray Archive, The Poetry of the Gentleman's Magazine, 1731-1800: An Electronic Database of Titles, Authors, and First Lines, and The Poetess Archive.

Reviewed by Kate Parker

University of Wisconsin-La Crosse

The (relatively) recent efflorescence of interest in the poetry of the eighteenth century-which roughly corresponds to the proliferation of electronic resources like Eighteenth Century Collections Online in the last decade-has inspired the development of scholarly websites dedicated to fostering exciting new work in the field. The best of these resources seek to connect researchers in innovative ways. While specialized in focus, each of the scholarly websites under review here has the potential to offer its readers a venue for extensive online collaboration: the Thomas Gray Archive (www.thomasgray.org) is a single-author archive that collects Gray's poetry and prose alongside prolific collaborative notes, providing an open-access scholarly edition of Gray's complete works; Emily Lorraine de Montluzin has chronicled the poetry published in Gentleman's Magazine from 1731-1800 (www.gmpoetrydatabase.org); and finally, The Poetess Archive (idhmc.tamu.edu/poetess) amasses works and criticism written in the poetess tradition - a historically undervalued popular genre of feminine writing which emerged during the " "bull market' of poetry" in Britain and America (1750-1900). One of these resources - the Gray Archive - makes ingenious use of crowdsourcing, capitalizing on growing networks of scholars and students to develop and expand its resources; similarly, the Poetess Archive has recently uploaded a number of scholarly presentations that feature its visualization tool for poetic elements.

The Thomas Gray Archive began as a research project at SUB Göttingen in 2000 and moved, with its editor Alexander Huber, to the Bodleian Libraries at Oxford in 2002. Its goal has always been collaborative: to develop an extensive online companion to Gray's poetry and prose compiled and disseminated in an open-access format. Such a project is particularly conducive to Gray's work because he is (as the site repeatedly points out) challenging and esoteric even for professional readers; Gray's biographer William Mason called him "the most learned man in Europe," as he spent the better part of his life immersed in study and took measurable pride in producing arcane verse (qtd. in Thomas). The collaborative notes aim to make the collective wisdom of Gray's former and contemporary readers accessible to all. I called up Gray's most celebrated poem, "Elegy Written in a Country Churchyard" (1751), and found that the Archive's edition of this 128-line poem contains an impressive 338 textual and 352 explanatory notes, easily accessible by clicking on a line which then expands to reveal the corresponding annotations. The first line ("The curfew tolls the knell of parting day") offered up 8 explanatory notes ranging from sources like W. Lyon Phelp's 1894 Selections from the Poetry and Prose of Thomas Gray to a contribution from Huber in 2009, along with 2 textual notes. The ability to expand and contract the commentary offers an intuitive reading experience preferable to other more disruptive formats (for example, jumping to hyperlinked footnotes at the end of the text). Since the line, when contracted, indicates how many notes are currently available for view, an added benefit is the ability to see, at a glance, which lines of text have received the most extensive commentary - a feature that would help direct an instructor's focus, for example, when teaching this poem in a seminar. 
The Archive is equally impressive in its inclusion and treatment of Gray's obscure works: for example, his Latin poems, like the "[Alcaic Ode]," or "[Latin verses at Eton]," also offer explanatory notes (including a helpful prose translation) and one can limit the search of available works exclusively to Latin, Greek or English offerings, or can filter by genre. Indeed, the site content is fully searchable, including supplemental resources like an extensive concordance, glossary, bibliography and chronology. The Archive also maintains a press-quality digital library of published editions of Gray's work as well as his complete correspondence; the editor has the laudable goal of eventually incorporating images of Gray's extant manuscripts, but at the present moment the site substitutes an extensive finding aid, which lists all identified manuscripts-as well as those copied by contemporaries and early editors-totaling some 290 artifacts.

While the Gray Archive supplies a substantive look at one of the mid-century's most celebrated poets, the strength of the Poetess Archive lies in its broad-indeed, often sweeping-panorama of one genre of eighteenth- and nineteenth-century popular poetry, a genre characterized by its feminized "domestic" focus, set in opposition to the "explicitly political" figure of the female poet (qtd. in Poetess). Part of the project of the Poetess Archive is to reframe the way in which popular poetry has historically been catalogued and studied, revealing how "lesser" literary genres have been underrepresented by research models that privilege single-author editions of poetry over miscellaneous versions (for example, individual poems appearing in literary annuals, magazines, etc.) In service of this revisionary project, the archive collects over 4,000 entriesboth poetry and criticism, in single-author editions as well as miscellanies, annuals and anthologies - concerned with the poetess tradition, composed by both male and female authors, in a searchable, peer-reviewed archive. However, the work of the Archive is still very much inprogress; the site boasts exciting visualization tools that will collect and represent data on poetic production from 1750 to 1900 in new-and arguably more expansive-ways, and a few tantalizing presentations featuring this tool have been uploaded in August 2013 (presumably, with more to come). The potential for collaboration and information-sharing here is quite exciting, the possibility of (re)visualizing popular poetry in a more relational, and ultimately more accurate, way is intriguing, but the Poetess Archive has only just begun to capitalize on both of these possibilities.

Similarly, de Montluzin's database is an exhaustive bibliography that enables one to search and locate any of the over 12,000 poems published in the Gentleman's Magazine from 1731 to 1800; currently, approximately 5,000 of these works have been attributed, many of them by de Montluzin herself. The extensive database - searchable by any number of useful limits, including author's name and first lines-is clearly an impressive undertaking, made even more so by the realization that this is a labor of love for de Montluzin, one generously made available to the public. Yet it has not fully benefited from the kinds of collaboration enabled by its presence on the web: for example, the author has not yet explored possible partnerships with resources like $E C C O$ or $E E B O$. (de Montluzin notes that, as of the last update, the approximately 7,600 unattributed poems have yet to be systematically run through these archives-a project that would inevitably tighten the gap between attributed and unattributed works. ${ }^{1}$ ) Yet what remains most exciting about this particular resource is how it attends not only to the poetry of literary giants, but to the poetry of the often much more intriguing minor players: the Gentleman's Magazine collects works from playwrights, musicians, schoolmasters, clergymen, professors and 
tradesmen, as well as several women poets, alongside its Pope, Swift, and Dryden. Indeed, de Montluzin's database acts as an important corrective to one of the most insidious misconceptions about eighteenth-century poetry by showing that, in fact, it is not an elitist form, but a much more common and popular mode of expression. And so I cannot resist the temptation to end this review with an analogy: the shared goals of these electronic archives - to create commonalities among scholars, to capitalize on a spectrum of readers, to enable legitimate open access to scholarship_-seem to nicely reflect the original goals of periodicals like the Gentleman's Magazine, which offered its own form of "open access." Indeed, all three of these archives, in different ways, invite us to meditate on the inherent value of scholarly community-in the eighteenth century, in the current moment, and in prospects for the future.

Note

${ }^{1}$ de Montluzin, Emily Lorraine. "Methodology of Assigning Authorial Attributions." The Poetry of the Gentleman's Magazine, 1731-1800: An Electronic Database of Titles, Authors, and First Lines. Web. 18 May 2013.

\section{Works Cited}

de Montluzin, Emily Lorraine, ed. The Poetry of the Gentleman's Magazine, 1731-1800: An Electronic Database of Titles, Authors, and First Lines. 2012. Web. 18 May 2013.<http://www.gmpoetrydatabase.org/db/>

Huber, Alexander, ed. Thomas Gray Archive. Thomas Gray Archive, 2013. Web. 15 May 2013. $<$ http://www.thomasgray.org $>$

Mandell, Laura, ed. The Poetess Archive. 2006. Web. 17 May 2013. <idhmc.tamu.edu/poetess> 